\begin{tabular}{|c|c|c|c|}
\hline \multirow{2}{*}{$\begin{array}{c}\text { LARUS } \\
\text { Hrvatska akademija } \\
\text { znanosti i umjetnosti }\end{array}$} & 51 & $\begin{array}{c}33-37 \text { str. } \\
1 \text { slika }\end{array}$ & Zagreb 2016. \\
\cline { 2 - 4 } & $(2016)$ & \multicolumn{3}{|c|}{$\begin{array}{c}\text { Primljeno 9. 9. 2016. } \\
\text { Prihvaćeno na sjednici Razreda za prirodne znanosti HAZU 24.10.2016. }\end{array}$} \\
\hline
\end{tabular}

UDK 598.293.1

Original scientific paper

\title{
IS THERE A TRADE-OFF BETWEEN CLUTCH SIZE AND EGG VOLUME IN MAGPIE Pica pica IN NORTHWESTERN CROATIA?
}

\section{Postoji li inverzija između veličine pologa i volumena jaja u svrake Pica pica u sjeverozapadnoj Hrvatskoj?}

\section{Zdravko Dolenec}

Mokrice 132, HR-49243 Oroslavlje, Croatia

\begin{abstract}
A negative relationship, or trade-off, between egg size (egg volume or egg mass) and clutch size is a central component of life-history theory. This paper presents evidence for a relationship between clutch size and egg volume (egg size) of the Magpie (Pica pica). Magpies are common and sedentary birds in study area. Egg characteristics were recorded in Mokrice rural area $\left(46^{\circ} 00^{\prime} \mathrm{N}, 1^{\circ} 55^{\prime} \mathrm{E}\right)$, northwestern Croatia; carried out during the breeding season (April-May) in the year 2012. I have not detected any negative correlation (trade-off) between mean estimated egg volume (egg size) and clutch size in the Magpie. The results indicate that, in researched Magpie population, in northwestern Croatia, there is a positively significant correlation between clutch size and egg volume. It can probably be explained by good environmental conditions and/or good quality females, which other authors offer as a plausible explanation. In conclusion, these results do not seem to support the prediction based on the theory of optimal egg/clutch size concerning the inverse relationship between egg size and clutch size.
\end{abstract}

Keywords: Magpie, Pica pica, egg volume, clutch size, trade-off hypothesis, northwestern Croatia

e.mail: dolenec@biol.pmf.hr 


\section{INTRODUCTION}

A central hypothesis of life-history theory is a trade-off between egg size (mass or volume) and clutch size (e.g. Sмith \& FreTwell 1974). Egg size combined with clutch size constitutes a major energetic investment of females; it could hence be expected that these two variables should be negatively correlated (ZIELINSKI \& BANbura 1998). Some papers demonstrated negative correlation between clutch size and egg size (e.g. Blackburn 1991, SAnches-Lafuente 2004), some positive (e.g. Encabo et al. 2001, Aslan \& Yavuz 2010), and the most papers report that clutch size and egg size were unrelated (e.g. Hepr et al. 1987, Fernandez \& REBoreda 2008, Hõrák et al. 2008, Polak 2010). A trade-off between clutch size and egg size, as assumed by optimal offspring size model, has been detected in other animal species; for example, in turtles (Rowe 1994). Furthermore, egg size is important for offspring survival in many bird species (e.g. SCHIFFERLi 1973, WILLIAMs 1994). Therefore, relationships between clutch size and egg size in birds have long attracted the interest of ornithologists.

This paper presents evidence for a relationship between clutch size and egg volume (egg size) of the Magpie (Pica pica). Magpies are common and sedentary birds in study area and population density was 4.79 pairs $/ \mathrm{km}^{2}$ (DOLENEC 2000). According to VAURIE (1959) the birds in my study area belong to the subspecies Pica pica pica.

\section{MATERIAL AND METHODS}

Egg characteristics were recorded in Mokrice rural area $\left(46^{\circ} 00^{\prime} \mathrm{N}, 15^{\circ} 55^{\prime} \mathrm{E}\right)$, northwestern Croatia; carried out during the breeding season (April-May) in the year 2012. This area is a mixed farming area with small meadows and arable land. The arable land contains small woods (up to $10 \mathrm{ha}$ ) dominated by Common Oaks Quercus robur and Hornbeams Carpinus betulus. All nests were found in bushes and deciduous trees. I measured the length ( $\mathrm{L}$, maximum, $\mathrm{mm}$ ) and breadth $(\mathrm{B}$, maximum, $\mathrm{mm}$ ) of eggs the nearest $0.01 \mathrm{~mm}$ with sliding calliper and calculated the volume $\left(\mathrm{V}, \mathrm{mm}^{3}\right)$ using the formula (Hort 1979): $\mathrm{V}=0.51 \mathrm{LB}^{2}$. Mean values of egg dimensions for full clutches were used as observation units in this paper. Characteristics in egg length, breadth and volume were based on clutch averages. Statistical analyses were performed using the SPSS 13.0 statistical package for Windows. All statistical tests were two-tailed, and the differences were considered significant at $\mathrm{p}=0.05$ or $\mathrm{p}<0.05$.

\section{RESULTS}

I measured 243 eggs from 45 nests in Mokrice rural area (NW Croatia). In this study (April-May 2012) Magpie clutches contained from 4 to 7 eggs. Mean clutch 
size was $5.41 \pm 0.889$ and modal clutch size was six. Mean values of egg dimensions are the following: egg length $33.95 \pm 1.44 \mathrm{~mm}$ (range: from 31.41 to $35.82 \mathrm{~mm}$ ), egg breadth $23.23 \pm 0.72$ (range: from 21.43 to $24.44 \mathrm{~mm}$ ), volume $9359.21 \pm 742.55 \mathrm{~mm}^{3}$ (range: from 7567.33 to $10692.62 \mathrm{~mm}^{3}$ ). Egg volume were positively correlated with clutch size (Pearson's correlation coefficient $(r)=0.355, \mathrm{p}=0.017, \mathrm{n}=45$; regression equation was $y=7758.24+296.68 x$; Figure 1 ).

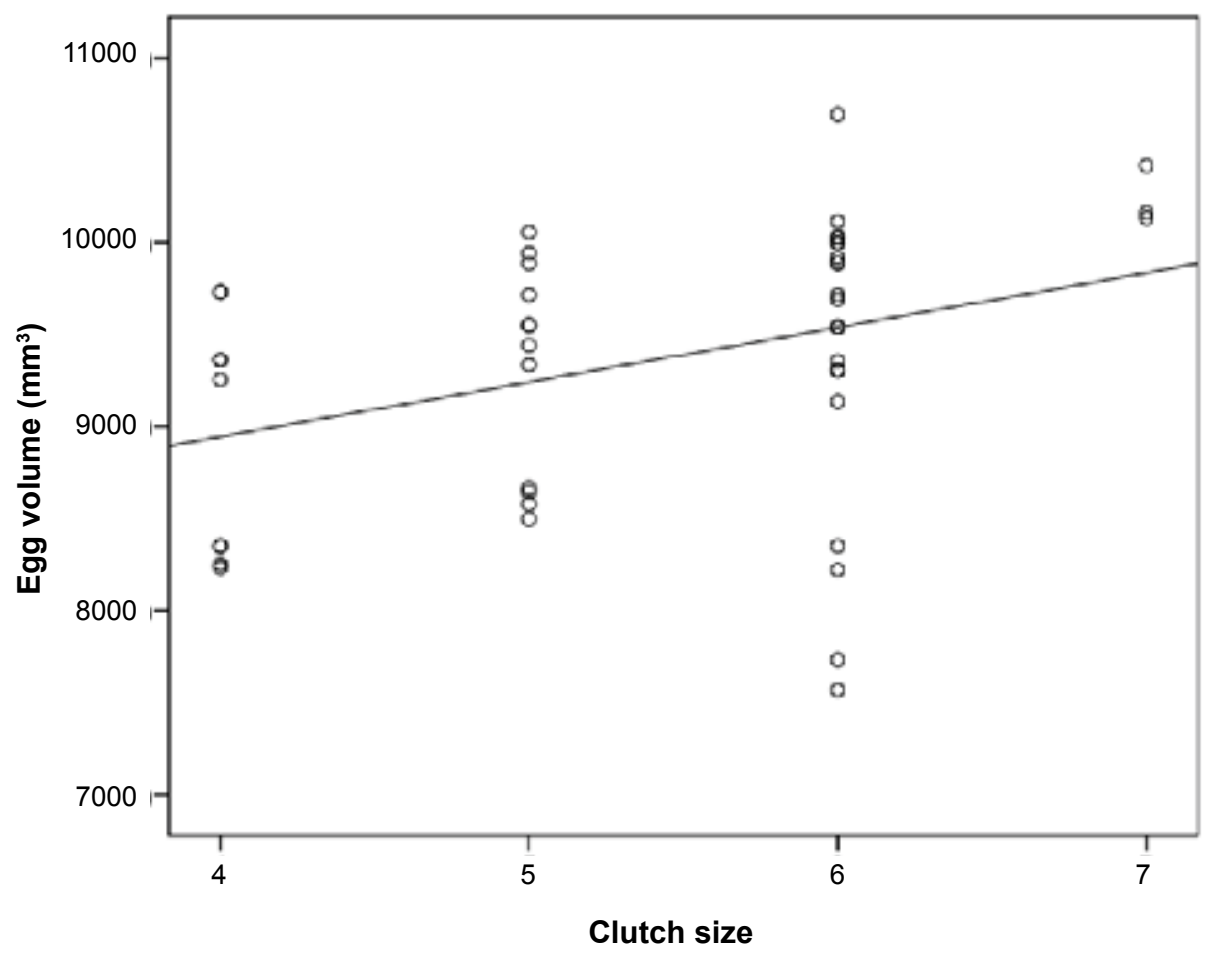

Figure 1. Relationship between clutch size and egg volume of the Magpie (northwestern Croatia), 2012 ( $r=0-355, p=0.017, n=45 ; y=7758.24+296.68 x)$.

Slika 1. Odnos veličine pologa i volumena jaja u svrake (sjeverozapadna Hrvatska), 2012. ( $r$ $=0-355, \mathrm{p}=0.017, \mathrm{n}=45 ; \mathrm{y}=7758.24+296.68 \mathrm{x})$.

\section{DISSCUSION}

A negative relationship, or trade-off, between egg size and clutch size is a central component of life-history theory, yet there is little empirical evidence for such a trade-off (WiLliams 2001). I have detected negative correlation between mean estimated egg volume (egg size) and clutch size in the Magpie. However, in this study mean egg size was positive related to clutch size. My finding is in agreement with results of some previous studies done on individual species (e.g. EnCABo et al. 2001, Aslan \& Yavuz 2010). According to Encabo et al. (2001), a pos- 
itive relationship between average egg size and average clutch size would have meant that, in good years, the birds produce large clutches of big eggs, while small clutches of small eggs would be produced in bad years. Furthermore, females in good condition after clutch completion tended to have larger clutches and laid significantly larger eggs in clutches than females in poor condition (LifJeld et al. 2005). All previous researches on trade-off hypothesis in Croatia have illustrated non-significant relationship between clutch size and egg size (Great Tit Parus major, Dolenec et al. 2005; Hooded Crow Corvus corone cornix, Dolenec 2006; Tree Sparrow Passer montanus, Dolenec et al. 2007; Common Starling Sturnus vulgaris, Dolenec et al. 2008 and Pied Wagtail Motacilla alba, Dolenec 2011).

In conclusion, the results indicate that, in researched Magpie population in northwestern Croatia, there is a positively significant correlation between clutch size and egg volume. It can probably be explained by good environmental conditions and/or good quality females, which other authors offer as a plausible explanation (e.g. JÄRVINEN 1996, LifJeld et al. 2005).

\section{References}

Aslan, A. \& Yavuz, M. (2010): Clutch and egg size variation, and productivity of the House Sparow (Passer domesticus): effects of temperature, rainfall, and humidity. Turk. J. Zool. 34: 255-266.

BlackвuRn, T. M. (1991): An interspecific relationship between egg size and clutch size in birds. Auk 108: 973-977.

Dolenec, Z. (2000): Breeding density, nest sites, clutch size and egg dimensions of the magpie (Pica pica) in NW Croatia. Nat. Croat. 9: 107-114.

Dolenec, Z. (2006): Nest density, clutch size and egg dimensions of the hooded crow (Corvus corone cornix). Nat. Croat. 15: 231-235.

Dolenec, Z. (2011): Some breeding traits of the pied wagtail (Motacilla alba) in NW Croatia. Nat. Croat. 20: 209-214.

Dolenec, Z., Mrakovčić, M., Delić, A. (2005): Egg dimensions of the Great Tit (Parus major L.) in Croatia. Pol. J. Ecol. 53: 1431-1445.

Dolenec, Z., Delić, A., Kralj, J., Dolenec, P. (2007): Variation in egg dimensions of the Tree Sparrow (Passer montanus L.) in north-western Croatia, Pol. J. Ecol. 55: 841-845.

Dolenec, Z., Kralj, J., Mustafić, P., Dolenec, P. (2008): Female biometrical characteristics and egg dimensions of the Starling (Sturnus vulgaris L.) in Croatia. Pol. Ecol. 56: 545548.

Encabo, S. I., Monros, J. S., Barba, E. (2001): Egg size variation in a Mediterranean Great Tit Parus major population. Ardeola 48: 63-70.

Fernandez, G. J.. Reboreda, J. C. (2008): Between and within clutch size variation of egg size in Greater Rheas. Wilson J. Orn. 120: 674-682.

Hepp, G. R., Stangohr, D. J., Baker, L. A., Kennamer, R. A. (1987): Factor affecting variation in the egg and duckling components of Wood Ducks. Auk 104: 435-443. 
Hõrák, D., Klvana, P., Albrecht, T. (2008): Why there is no negative correlation between egg size and number in the Common Pochard? Acta Oecol. 33: 197-202.

Hoyt, D. F. (1979): Practical methods of estimating volume and fresh weight of birds. Auk 96: 73-77.

Järvinen, A. (1996): Correlation between egg size and clutch size in the Pied Flycatcher Ficedula hypoleuca in cold and warm summers. Ibis 138: 620-623.

Lifjeld, J. T., Johnsen, A., Petitguyot, T. (2005): Egg-size variation in the bluethroat (Luscinia s. svecica): constraints and adaptation. J. Orn. 146: 249-256.

Polak, M. (2010): Clutch and egg size variation in the coot Fulica atra breeding on fishponds in eastern Poland - test of the optimal egg dimensions hypothesis. Acta Zoolog. Cracov. 53A: 35-40.

Rowe, J. W. (1994): Reproductive variation and the egg size-clutch size trade-off within and among populations of painted turtles (Chrysemys picta beli). Oecologia 99: 35-44.

SAnches-Lafuente, A. M. (2004): Trade-off between clutch size and egg mass, and their effects on hatchability and chick mass in semi-precocial Purple Swamphen. Ardeola 51: 319-330.

Schifferli, L. (1973): The effect of egg weight on the subsequent growth of nestling Great Tit Parus major. Ibis 115: 549-558.

Sмith, C. C., Fretwell, D. D. (1974): The optimal balance between size and number of offspring. Am. Nat. 108: 499-506.

Williams, T. D. (1994): Intraspecific variation in egg size and egg composition in birds: Effects on offspring fitness. Biol. Rev. 68: 35-59.

Williams, T. D. (2001): Experimental manipulation of female reproduction reveals an intraspecific egg-clutch size trade-off. Proc. R. Soc. Lond. B: 268: 423-428.

VAurie, C. (1959): The birds of Palearctic Fauna. Witherby, London.

Zieliński, P., Bańbura, J. (1998): Egg size variation in the Barn Swallow Hirundo rustica. Acta Orn. 33: 191-196.

\section{SAŽETAK}

Veličina jaja koje ptica treba snesti jedan je od prvih „problema“ svake ženke tijekom reprodukcijskog ciklusa. Ovo istraživanje trebalo je dati odgovor na teoretsku pretpostavku prema kojoj bi u gnijezdima s porastom broja jaja trebao padati volumen (ili masa) jaja. Međutim, u ovom istraživanju rezultati su suprotni, povećanjem broja jaja raste volumen jaja u svrake Pica pica. To je zabilježeno i kod neki drugih ptičjih vrsta. Tumači se „dobrim godinama“ i/ili „dobrim stanjem“ ženke u razdoblju gniježđenja. Zaključno, rezultati istraživanja svrake na području sjeverozapadne Hrvatske ne podržavaju „hipotezu ustupka" (inverzije između veličine jaja i veličine pologa). 